\title{
What do secondary education students understand about Social Justice? Students representations of social justice in different regions of Spain
}

\begin{abstract}
This quantitative empirical research analyses secondary school students' representations of social justice in different regions of Spain. 'Social Justice Representation Questionnaire- SJRQ' has been designed and implemented to conduct an empirical analysis of Social Justice in the field of education. This instrument is based on the three dimensional model of social justice (redistribution, recognition and representation). Participants of this study were 3229 secondary education students from 12 to 21 years old. The participants belong to 20 public schools in five Autonomous Communities of Spain. This study aims to determine how the concept of social justice develops in secondary education students of different educational levels and whether gender is a relevant variable. The results confirm that social justice representations of secondary education students follow a developmental trend because students of upper educational levels have a closer vision to social justice. Also, females manifest a greater predisposition towards social justice than males. This study confirm that SJRQ is a useful tool to train Social Justice oriented citizens and to develop training programs adapted to different understanding levels.
\end{abstract}

Keywords: Social Justice, Education, Redistribution, Recognition, Representation

\section{Introduction}

Today we face a world full of great injustices, inequalities and inequities that are present in many areas of people's lives. These situations of lack of equity and justice have led to increased awareness and common interest in building an increasingly fair and equitable society, generating an interesting debate in recent decades on the different uses and meanings of social justice.

Social Justice is a complex and contested concept that has been used in many different contexts and from very distinct purposes with distinct meanings from different disciplines (Novak, 2000). In this context, many authors (Fraser, 2008; Rawls, 1971; Sen, 2009; Miller, 1999; Nussbaum, 2006; Young, 1990) have shown the importance of considering social justice as one of the fundamental goals that society must pursue. This study assumes the concept of social justice based on the approaches of Rawls (1971), Sen (2009) and Nussbaum (2011) as redistribution of resources and capabilities, added to the ideas of Fraser (2008), and its defense of recognition and participation or representation as complementary elements. This model of the three dimensions of Social Justice: redistribution, recognition and representation, has been also developed by other authors (Murillo \& Hernández-Castilla, 2011; Tikly \& Barrett, 2011; Walker, 2006), who apply the proposal to educational field.

This study is based on the tridimensional approach of Social Justice proposed by Nancy Fraser (2008, 2009), constituted by redistribution, recognition and representation.

It has been widely demonstrated that education plays a fundamental role in achieving the promotion of social justice (Blum, Wilson \& Patish, 2015; Lalvani, 2013; Nussbaum, 2011). 
To promote an education for social justice, educators must begin by knowing what kind of representations students have about social justice. That is, they need to know what representations students have about the different situations of injustice and inequity that occur in different settings and contexts (educational, social, cultural, political, economic, etc.); what kind of approach they adopt to interpret what happens in schools and classrooms, and also in societies, and to what extent they are able to identify and question inequities and injustices from a social justice perspective (Adams \& Bell, 2016; McDonald, 2005; 2008). It is necessary to develop studies that analyze representations that students have about different situations related to social justice.

Currently, there are very few studies that have been carried out to evaluate how the representations of social justice develops in secondary school students (Jornet-Meliá, Sancho-Álvarez \& Bakieva, 2015, SepúlvedaParra et al., 2016). None of these proposes a quantitative and holistic evaluation of social justice representations based on the three dimensions of redistribution, recognition and representation. It is necessary to develop relevant and appropriate instruments that allow us to understand the vision of young people from the three dimensional model of social justice. Our study intends to contribute to this aim, using quantitative methodology to analyze these representations.

Only when students are aware of social inequalities could they have an interest in intervening on injustices. As Goodman (2000) upholds, in order to address inequalities and commit oneself to social justice in the first place, one must be aware of the existence of these injustices. There are studies (Miller et al., 2009; Miller \& Sendrowitz, 2011; Torres-Harding, Steele, Schulz, Taha \& Pico, 2014) that support the relationship between the representation that students have about social justice and their involvement and commitment with their school.

Following the proposal of Bonnycastle (2011) and other previous studies (Ludlow et al., 2008; Patterson et al., 2012), this research assumes social justice representations through a continuum that fluctuates from more unjust - or less just - representations to more just representations or strong commitments by social justice.

This study was conducted in Spain, a country organized in seventeen autonomous communities. In the field of education, its territorial organization implies the adoption of a management model that distributes the competences between the General State Administration and the autonomous communities. Demographic changes in the population pyramid with greater aging and the migratory movements, have affected the composition of students, posing a challenge for professionals of education. Likewise, changes, political instability and the different educational policies have also influenced the current education system. These social, demographic and political characteristics make it especially interesting to develop this study in Spain.

In Spain, basic and compulsory education is currently divided into two stages: Primary Education (EP) from 6 to 12 years old and Secondary Education (ESO) from 12 to 16 years old. There is also a stage of non-compulsory secondary education (from 16 to 18 years old), called baccalaureate (Bach.).

The purpose of this study is to analyze the representations that Spanish adolescents have about social justice. In order to understand what young people think about social justice issues, an empirical analysis was 
conducted to evaluate social justice representations through its three intrinsic dimensions (redistribution, recognition and representation).

This study aims to determine how secondary education students' representations of social justice develops across different educational levels, and whether gender is a relevant variable. Based on the results of previous research on social justice (Hurtado et al., 2002; Ludlow et al., 2008; Murillo et al., 2014) we expect females to have higher levels of social justice representations than males. In addition, we hope to find a developmental trend in the representations of social justice of the secondary education students. That is, students who in their later years of secondary education are expected to present more elaborate and prosocial representations than students who are younger.

\section{Conceptualization of social justice}

For many years, issues surrounding distributive justice have dominated the discourse of social justice (Dworkin, 1981; Miller, 1999; Rawls, 1971; Sen, 2009). In some cases, 'social justice' and 'distributive justice' have been used interchangeably to refer to the intention of ensuring that everyone receives what they are owed (Miller, 1999). So much so that redistributive claims have been the most influential paradigm in most of the theories surrounding social justice over the last 150 years (Cazden, 2012).

The traditional view of redistributive injustices has remained anchored to the differences of social class based on the power and wealth that continue to exist in the capitalist society in which we find ourselves. As Stiglitz (2012) argues, wealth is distributed very unevenly, so much so that the richest $1 \%$ of the population concentrates most of the wealth and owns what the remaining 99\% needs. Distributive justice aims to advance in this model of perpetuating classes and reproducing status, enabling mobility between groups for the benefit of those who are worse off. In this context, social institutions and public agencies must influence the distribution of opportunities, income, wealth and social advantages to ensure that everyone has the same opportunities.

The development of this redistribution should be considered in terms of equity, granting a differentiated treatment that supports the most vulnerable or disadvantaged groups with greater resources in order to eliminate or reduce inequalities from the beginning (Rawls, 1971).

As stated by Sen (2009), poverty is not only determined by lack of income, but also by the lack of basic capabilities. Sen (2009) and Nussbaum (2011) approach is also based on the redistributive dimension of justice, but in terms of capabilities. In order to guarantee social justice, it is necessary to ensure that people are free to choose from different ways of life, that is, it is necessary to ensure people's capabilities, understood as their real opportunities to do and be what they have reason to value.

The concept of 'redistribution' in social justice joins the notion of 'recognition' (Cole, 2017; Fraser \& Honneth, 2003; Honneth, 2007; Irvine, 2003; Taylor, 1993; Young, 1990; Young \& Nussbaum, 2013) which is linked to the visibility and the social and cultural respect of all people. , This will be achieved through the positive assessment of the riches that this diversity provides.

For recognition to exist there must be an absence of cultural and social domination, assuring justice to minority or traditionally-excluded groups for reasons of gender, culture, social class, ethnicity or sexual 
orientation. This will be possible by promoting positive discrimination towards groups at a disadvantage, transforming the societal patterns of oppression and assimilation by hegemonic culture. The aim is to achieve a world that is welcomes differences, where assimilation to dominant cultural norms is no longer the reference to follow (Cazden, 2012).

Following the historical development of the concept of social justice, to the dimensions of 'redistribution' and 'recognition', the dimension of 'representation' or 'participation' is introduced (Fraser, 2008, Lynch \& Lodge, 2002, Miller, 1999). 'Representation' is associated with the active participation of people, especially groups traditionally excluded in decisions that affect their own lives.

In order to achieve an adequate redistribution and recognition, it is necessary the participation of the affected people by injustices in the decision-making processes in the different spheres of social life.

Therefore, following Fraser (2008) we bet on a three-dimensional and interactional model of social justice, combining redistribution, recognition and representation that have influence in all areas of society. Thus, the scope of social justice will be achieved through:

- Redistribution of material and cultural resources, primary goods and capacities.

- Recognition of difference and cultural respect for each and every person, giving value, empowerment and celebration to diversity.

- Representation or active participation of all citizens in every important sphere of social life, and especially in the decisions that affect their own lives.

\section{Social Justice in Education}

In the field of education, there is no doubt that social justice issues have generated a broad concern by theoreticians, researchers, teachers and the entire educational community (Adams \& Bell, 2016; Apple, 2009; Ayers, Quinn \& Stovall, 2009; Brighouse, 2000; Cazden, 2012; Gewirtz, 2006; Zeichner, 2009).

In fact, within the field of education some authors maintain a critical position pointing out that most social justice educational work carried out in this field adopt rather a diffuse and ambiguous theoretical approach to social justice, without making explicit reference to the social, political, historical and philosophical roots on which it is based (Cochran-Smith, 2008; Gewirtz, 2006; North, 2006; Reagan et al., 2016).

In this study, following the approach of several authors (Murillo \& Hernández-Castilla, 2011, Tikly \& Barrett, 2011, Walker, 2006), the three-dimensional model of social justice (redistribution, recognition and representation) is applied to the educational field:

1. An equitable redistribution of resources and support is necessary to give the most disadvantaged students greater possibilities of development, granting each student according to their specific needs and their starting situation, and ensuring the same learning possibilities (Cochran-Smith, 2010), the development of capabilities (Sen, 2009; Nussbaum, 2011) and access to quality education for all students (Bolívar, 2016; Lalvani, 2013).

2. In addition, greater recognition of traditionally-excluded students is important. An appreciation of diversity that promotes respect and celebration of the individual, social and cultural differences of all students. A heterogeneous and multicultural curriculum should be built, which includes issues related to diversity, valuing identities or cultures that are traditionally not respected. 
3. Finally, there is also a need for greater participation and representation of students who are traditionally excluded, in order to understand their learning and life needs. This gives students a voice in debates and guarantees the active and effective participation of all members of the educational community in decision-making, in an environment of freedom and fair coexistence.

Thus, social justice in education should promote social mobility -through redistribution, recognition and representation-, giving the most disadvantaged students the possibility of extending their schooling and ascending the social scale by receiving a good quality education (Gewirtz, 2006Tikly, 2010).

From this perspective of social justice, the aim is to train social justice oriented citizens (Westheimer, 2015) who are actively involved and concerned about solving the deepest causes of all injustices.

\section{Previous Scales of social justice}

To date, several instruments have been developed with the intention of evaluating different issues related to social justice from distinct approaches and fields of study (Chen-Hayes, 2001; Ludlow, Enterline \& Cochran-Smith, 2008; Marszalek, Barber \& Nilsson, 2017; Miller et al., 2009; Murillo, Hernández-Castilla, Hidalgo \& Martínez-Garrido, 2014; Nilsson, Marszalek, Linnemeyer, Bahner \& Misialek, 2011; Rasinski, 1987; Ritchhart, 2002; Torres-Harding, Siers \& Olson, 2012). Table 1 shows the name of these scales with their authors and the year of elaboration, type of participants, field of study and social justice dimensions evaluated.

Table 1 shows the name of these scales with their authors, years of elaboration, type of participants, field of study in which it has been applied and social justice dimensions evaluated.

Table 1 Scales and instruments related to social justice.

\begin{tabular}{|c|c|c|c|c|}
\hline Author / s (year) & Name of the Scale & $\begin{array}{c}\text { Dimension } \\
\text { of SJ }\end{array}$ & Field of study & Participants \\
\hline Rasinski (1987) & Proportionality Scale & $\mathrm{R} 1$ & Political philosophy & Undergraduates \\
\hline Chen-Hayes (2001) & Social Justice Advocacy Readiness Questionnaire & $\mathrm{R} 2, \mathrm{R} 3$ & Education & No applied \\
\hline Ritchhart (2002) & Social Activism Beliefs Rating Scale (SABR) & R3 & Psychology & Professionals \\
\hline Corning \& Myers (2002) & Activism Orientation Scale & R3 & Social psychology & Undergraduates \\
\hline Ludlow et al. (2008) & Learning to teach for Social Justice-Beliefs (LTSJ-B) & $\mathrm{R} 1, \mathrm{R} 2$ & Education & Graduates \\
\hline Miller et al. (2009) & The Social Issues Questionnaire (SIQ) & $\mathrm{R} 2, \mathrm{R} 3$ & $\begin{array}{c}\text { Social-Cognitive } \\
\text { psychology }\end{array}$ & Undergraduates \\
\hline Nilsson et al. (2011) & The Social Issues Advocacy Scale (SIAS) & $\mathrm{R} 2, \mathrm{R} 3$ & Psychology, Education & adult population \\
\hline Torres-Harding et al. (2012) & Social Justice Scale (SJS) & $\mathrm{R} 2, \mathrm{R} 3$ & Education & $\begin{array}{c}\text { Undergraduates/ } \\
\text { Graduates }\end{array}$ \\
\hline Murillo et al. (2014) & Scale of Attitudes towards social justice in Education (EAJSE) & $\mathrm{R} 2, \mathrm{R} 3$ & Education & $\begin{array}{c}\text { Undergraduates/ } \\
\text { Professionals }\end{array}$ \\
\hline Marszalek et al. (2017) & Social Issues Advocacy Scale-2 (SIAS-2) & $\mathrm{R} 2, \mathrm{R} 3$ & Psychology, Education & Professionals \\
\hline
\end{tabular}

On Redistribution dimension, Rasinski (1987) developed Proportionality Scale, to measure the degree to which people use principles of proportionality (equal opportunities) or egalitarianism (equal results) to promote the scope of Social Justice.

In relation to Representation dimension, Activism Orientation Scale (Corning and Myers, 2002) assesses beliefs about the influence political processes and their activist behaviors. However, political activism is 
only one component of Social Justice linked to Representation dimension. From the psychological discipline, Social Activism Beliefs Rating Scale-SABR (Ritchhart, 2002) evaluates the activism and attitudes of psychologists towards Social Justice in their professional roles. This scale is limited for Social Justice in the field of psychology, with difficulty to be applied to different populations.

From a broader perspective, considering the dimensions of Recognition and Representation, other scales (Marszalek et al., 2017; Miller et al., 2009; Nilsson et al., 2011; Torres-Harding et al., 2012) evaluate values, attitudes, subjective norms and intentions related to Social Justice.

Focusing on education, Social Justice Advocacy Readiness Questionnaire (Chen-Hayes, 2001), assesses awareness, level of commitment and values of teachers to prepare for Social Justice in different groups. Learning to Teach for Social Justice-Beliefs-LTSJ B (Ludlow et al., 2008) measures teachers' beliefs about redistribution of resources, opportunities and learning outcomes, and recognition of traditions, knowledge and strengths of students. Scale of Attitudes towards social justice in Education-EAJSE (Murillo et al., 2014), assesses attitudes and teaching personal commitment towards Social Justice in Education.

The instruments developed so far tend to analyze social justice through Likert scales, without promoting reflection through the analysis of dilemmas or specific social justice situations. In addition, none of these instruments evaluate social justice representations of secondary education students based on Redistribution, Recognition and Representation. To analyze these representations of social justice, it is important to contextualize the situations to provide a more concrete vision of the reality studied.

\section{Previous studies of social justice with students}

With regard to student representations of social justice, a number of recent studies have been carried out from different theoretical approaches. Most of these studies focus on analyzing the perceptions of university students (Beer, Spanierman, Greene \& Todd, 2012; Corning \& Myers, 2002; Hurtado, Engberg, Ponjuan \& Landreman, 2002; Ludlow et al., 2008; Miller et al., 2009; Miller \& Sendrowitz, 2011; Murillo et al., 2014; Nilsson \& Schmidt, 2005; Rasinski, 1987; Torres-Harding et al., 2014) or professionals (Caldwell \& Vera, 2010; Marszalek et al., 2017; Ritchhart, 2002) have about issues related to social justice. However, there are much fewer studies that have analyzed the perceptions that secondary education students have towards social justice issues (Jornet-Meliá et al., 2015, Sepúlveda-Parra et al., 2016).

The results of some studies (Broido, 2000; Torres-Harding et al., 2014) have shown that the students' representation on social justice is related to egalitarian values, with acceptance and respect towards differences, participation in making decisions, and taking action against injustices.

In the research carried out by Sepúlveda-Parra et al. (2016) it has become clear that the concept of social justice that secondary school students have is more closely associated with their own experiences of participating in democratic spheres of their lives, which correspond to the social justice dimensions of representation and participation. To a lesser degree, the dimension of recognition and acceptance of diversity, and of the redistributive dimension from an egalitarian and inequitable perspective are reported.

Several studies (Beer et al., 2012; Hurtado et al., 2002; Ludlow et al., 2008) have shown that there are demographic variables such as being female, belonging to middle class or ethnic minorities, or have close 
contact with disadvantaged groups, that would favourably impact towards a more social justice-centered orientation.

Focusing on gender dimension, in the study by Ritchhart (2002) no differences between females and males in Social Justice were found. In the research of Nilsson \& Schmidt (2005), males reported a greater desire to engage in social justice than females although no differences were found in their real level engagement. Other studies (Hurtado et al., 2002; Murillo et al., 2014) have found that females are more likely than males to report democratic values and social justice beliefs.

Several studies have been conducted in order to evaluate and predict behaviors and commitment towards social justice based on the interests, attitudes and perceived self-efficiency in social justice shown by the students (Miller et al., 2009; Miller \& Sendrowitz, 2011; Nilsson \& Schmidt, 2005; Torres-Harding et al., 2014). But the opposite is also true, the behaviours that occur in schools impact on the perception that students have about social justice (Jornet-Meliá et al., 2015). In addition, participation in volunteer activities, attendance at diversity programs or coexistence with multicultural friendships seem to be strong predictors of students' involvement in social justice (Hurtado, 2006). On the other hand, being exposed to situations of injustice and the influence of significant people are also variables that influence the orientation towards social justice (Caldwell \& Vera, 2010).

\section{Method}

\section{Participants}

Participants of this study were 3229 secondary education students from the following educational levels: $2^{\text {nd }}$ of Compulsory Secondary Education ' $2^{\circ}$ ESO' (typically 13-14 years old), $4^{\text {th }}$ of Compulsory Secondary Education ' $4^{\circ}$ ESO' (typically 15-16 years old) and $2^{\text {nd }}$ of Baccalaureate ' 2 ' Bachillerato (Bach.)' (typically 17-18 years old). The mean age of students in these educational levels were 13,15 and 17 years respectively. Table 2 shows the sample of the participants, distributed by educational level, age range and gender.

Table 2 Distribution of participants by academic year, age range and gender

\begin{tabular}{lcccc}
\hline $\begin{array}{c}\text { Educational } \\
\text { Level }\end{array}$ & Age range & Male & Female & Total \\
\hline $2^{\mathbf{o}}$ ESO & $12-16$ & 599 & 607 & 1209 \\
$4^{\text {o }}$ ESO & $14-19$ & 518 & 596 & 1116 \\
$2^{\text {o }}$ Bach. & $16-21$ & 446 & 457 & 904 \\
Total & $\mathbf{1 2 ~ - 2 1}$ & $\mathbf{1 5 6 3}$ & $\mathbf{1 6 6 0}$ & $\mathbf{3 2 2 9}$ \\
\hline
\end{tabular}

In order to select the sample, a probabilistic sampling stratified by clusters was carried out. The selected strata were five regions in Spain known as 'Autonomous Communities' (Madrid, Castilla y León, Andalusia, Extremadura and Basque Country). The selection of these Communities was justified by the fact that these five communities exhibit a number of different characteristics in terms of social and economic issues as well as in the administration of education. In order to select students, a stratified sample proportional by clusters was carried out. The strata selected were the Autonomous Community. Participants were selected from 20 public secondary education schools, 5 from each region with the objective of having 
a representative sample, as complete as possible, of secondary school students from different territories of Spain.

\section{Instrument}

In order to carry out the study, the 'Social Justice Representation Questionnaire' (SJRQ) has been applied. This instrument was designed by a group of experts from the research group "Educational Change for Social Justice" (GICE) from the Faculty of Teacher Training and Education of the Universidad Autónoma de Madrid (Authors).

This questionnaire consisted of 30 dilemmas, classified according to the three dimensions of social justice (10 dilemmas of Redistribution, 10 dilemmas of Recognition and 10 dilemmas of Representation). The questions posed different hypothetical dilemmas based on current situations, which were related to real debates that have been raised in the public sphere regarding issues related to social justice. The questionnaire included a wide variety of social problems on various current issues such as: distribution of goods and resources, discrimination, racism, sexism, homophobia, citizenship, migration, participation, family diversity, education policies, democracy and globalization, among various others. Each dilemma has three response options distributed in a continuum of social justice. One of the options represented the highest degree of social justice, another option was in a position of intermediate social justice, and the other option was in a lower degree in social justice.

Figure 1 shows an example of one of the dilemmas belonging to the 'redistribution' dimension of social justice.

\section{Andrea is 8 years old and always goes to school in a wheelchair. The playground is a sandy area, and her family has requested that a part of this should be paved with a flat and firm surface to make it easier for her to go outdoors and play with the other children. This work is expensive. Which option would you support?}

A) Spend whatever is necessary and begin the works as soon as possible, so that Andrea can go out and play just like the others.

B) Fix at least half the playground so that she can go out and play.

C) Spend more on improvements that will benefit the majority, and seek an alternative solution to individual cases such as this.

Fig. 1 Sample dilemma for the 'redistribution' dimension

In the example proposed in Figure 1, option A represents the highest degree of social justice, alternative C raises the response with the lowest social justice degree, and option B shows an intermediate position between these two.

Before applying the questionnaire, was subjected to a double validation process: validation of experts and a pilot test. To analyze the validity of content and construction of the questionnaire, the criterion of 13 expert judges within different fields of social justice was used. Thus, each of the three response options for the 30 dilemmas were evaluated by these external judges in order to determine the degree of social justice attributed by them on a scale of 1 to 9 , with respect the dimension evaluated in each dilemma (redistribution, recognition or representation). In addition, to verify that the language was adjusted to the understanding of the participants, the instrument was reviewed by an expert in adolescent's discourse. 
An experimental application of the instrument was also conducted to a pilot sample of 130 postgraduate Master's degree students at Universidad Autónoma de Madrid, who were training to qualify as secondary education teachers. The reliability value obtained in Cronbach's alpha coefficient was $\alpha=0.74$

\section{Procedure}

This research was carried out by an interdisciplinary research group at the Universidad Autónoma de Madrid (GICE: http://www.gice-uam.es/), who work on issues related to educational change for social justice from different perspectives and approaches.

First, the ethics committee of the Universidad Autónoma de Madrid conducted an evaluation of the questionnaire. In addition, for the administration of the questionnaires, children and families gave their informed consent to research participation. Subsequently, the documents were handed out in printed format at the corresponding schools. The participants were informed that the answers were anonymous and they had to answer all the questions by selecting only one of the options.

In the evaluation phase, a score of 1 was assigned for the less fair alternative, 2 for the intermediate social justice alternative and 3 for the fairer alternative. Subsequently, we have proceeded to add the scores grouping the questions according to the dimension to which they belonged. In this way, three types of specific subscales (Social Justice Subscales) were obtained for each dimension (Redistribution, Recognition, and Representation). In addition, a Global Social Justice Scale was obtained by the integration of these three previous subscales and, therefore, of all the items that make up the questionnaire.

The scores of the specific subscales and the general scale were adapted to a range of 0 to 100 to facilitate their analysis and interpretation. Once the scales were adapted, the social justice comparison analysis was carried out, according to the gender and the educational level of the participants.

The last step in the study was the return of information to every schools through a report of the results obtained.

\section{Design and data analysis}

An ex post-facto quantitative exploratory research project was carried out to learn about the ideas that young adolescents in our contemporary society had about issues related to social justice. Through a crosssectional empirical study, we analyzed the representations that students from different educational levels in one academic year (2015/2016).

The analysis of the data was done with the SPSS computer software in its IBM Statistics 22 version.

\section{Results}

\section{Global Social Justice Scale}

With regard the Global Social Justice Scale, the results obtained show the existence of a developmental and educational trend in the representations that students have about social justice. This means that as the level of education among students increases, higher mean social justice scores are obtained by the groups. In addition, the mean scores obtained in the groups of females are higher than the mean scores of males. The size of the groups samples, their mean scores and standard deviations can be observed in Table 3 . 
Table 3 Descriptive statistics by gender and educational level

\begin{tabular}{ccccc}
\hline Educational Level & Gender & $N$ & $M$ & $S D$ \\
\hline \multirow{2}{*}{$2^{\circ}$ ESO } & Female & 607 & 65.69 & 9.17 \\
$(13-14$ yrs $)$ & Male & 599 & 61.09 & 11.33 \\
& Total & 1206 & 63.41 & 10.55 \\
& & & & \\
$4^{\circ}$ ESO & Female & 596 & 71.43 & 8.75 \\
$(15-16$ yrs $)$ & Male & 518 & 67.81 & 10.27 \\
& Total & 1114 & 69.75 & 9.65 \\
& & & & \\
$2^{\circ}$ Bach & Female & 457 & 74.16 & 8.15 \\
$(17-18$ yrs $)$ & Male & 446 & 71.14 & 11.16 \\
& Total & 903 & 72.67 & 9.86 \\
& & & & 9.42 \\
Total & Female & 1660 & 70.08 & 11.72 \\
& Male & 1536 & 66.19 & 10.77 \\
\hline
\end{tabular}

An analysis of variance of 'Gender' $\mathrm{x}$ 'Educational level' was carried out to check if there were significant differences in the variables gender (males, females) and educational level ( $2^{\circ} \mathrm{ESO}, 4^{\circ} \mathrm{ESO}, 2^{\circ} \mathrm{Bach}$.).

Table 4 Differences by educational level, gender and their interaction in the Global Social Justice Scale

\begin{tabular}{lccccc}
\hline \multicolumn{1}{c}{ Origin } & $\begin{array}{c}\text { Type III sum } \\
\text { of squares }\end{array}$ & df & F & Sig & $\begin{array}{c}\text { Partial eta } \\
\text { squared }\end{array}$ \\
\hline Gender & 11124.243 & 1 & 114.188 & $.000^{* * *}$ & .034 \\
Educational Level & 47979.517 & 2 & 246.249 & $.000^{* * *}$ & .133 \\
Gender x Ed. Level & 337.724 & 2 & 1.733 & .117 & .001 \\
Error & 313402.179 & 3217 & & & \\
${ }^{* * *} . p<.001$ & & & & &
\end{tabular}

The results of Table 4 show that there are statistically significant differences in the gender variable $(\mathrm{F}$ $\left.1.3217=114.19 ; \mathrm{p}<.001 ; \eta^{2}=.034\right)$. In this case, $3.4 \%$ of the variance is explained by the differences between the mean scores obtained by males and females.

After performing a post hoc contrast analysis with the Bonferroni statistic, it was found that the differences by gender are statistically significant $(\mathrm{p}<.001)$ in favour of females. These have obtained higher mean values $(M=70.08, S D=9.42)$ than males $(M=66.19, S D=11.72)$.

Regarding the educational level variable, there are also statistically significant differences $\left(\mathrm{F}_{2.3217}=246.25\right.$; $\left.\mathrm{p}<.001 ; \eta^{2}=.133\right)$. Thus, $13.3 \%$ of the variance is explained by the differences between educational levels. The post hoc analysis with the Bonferroni statistic shows significant differences $(p<.001)$ along all the educational levels. Analyzing the mean scores obtained by students of the different educational levels, it can be observed that there is a tendency to obtain greater mean scores in the global social justice scale in 
the upper grades. That is, means scores increase when the educational level is higher, i.e. moving up the school years: $M=63.41(S D=10.51)$ in $2^{\text {nd }}$ of Secondary Education $\left(2^{\circ} \mathrm{ESO}\right), M=69.75(\mathrm{SD}=9.65)$ in $4^{\text {th }}$ of Secondary Education $\left(4^{\circ} \mathrm{ESO}\right)$, and $M=72.67(S D=9.86)$ in $2^{\text {nd }}$ of Baccalaureate $\left(2^{\circ}\right.$ Bach. $)$.

An analysis of multiple comparisons with the Bonferroni statistic shows that the statistically significant differences ( $\mathrm{p}<.001)$ between males and females appear in all educational levels. In all groups, females obtained higher mean scores than males in the Global Social Justice Scale. These results can be seen in Table 5.

Table 5 Analysis of multiple comparisons with Bonferroni

\begin{tabular}{lccccccc}
\hline $\begin{array}{c}\text { Educational } \\
\text { Level }\end{array}$ & $\begin{array}{c}\text { Gender } \\
(\mathrm{I})\end{array}$ & $\begin{array}{c}\text { Gender } \\
(\mathrm{J})\end{array}$ & $\begin{array}{c}\text { Mean } \\
\text { difference }(\mathrm{I}-\mathrm{J})\end{array}$ & $\begin{array}{c}\text { Standard } \\
\text { error }\end{array}$ & Sig. & $\begin{array}{c}\text { Lower } \\
\text { limit }\end{array}$ & $\begin{array}{c}\text { Upper } \\
\text { limit }\end{array}$ \\
\hline $2^{\circ}$ ESO & Female & Male & 4.597 & .568 & $.000^{* * * *}$ & 3.482 & 5.711 \\
$4^{\circ}$ ESO & Female & Male & 3.624 & .593 & $.000^{* * * *}$ & 2.462 & 4.787 \\
$2^{\circ}$ Bach. & Female & Male & 3.018 & .657 & $.000^{* * * *}$ & 1.730 & 4.306 \\
F**** $p<.001^{*} p$ & & & & & & &
\end{tabular}

The results of the mean scores of the interaction between the gender and educational level variables in the Global Social Justice Scale are shown in Figure 2. At all educational levels, females obtained higher mean

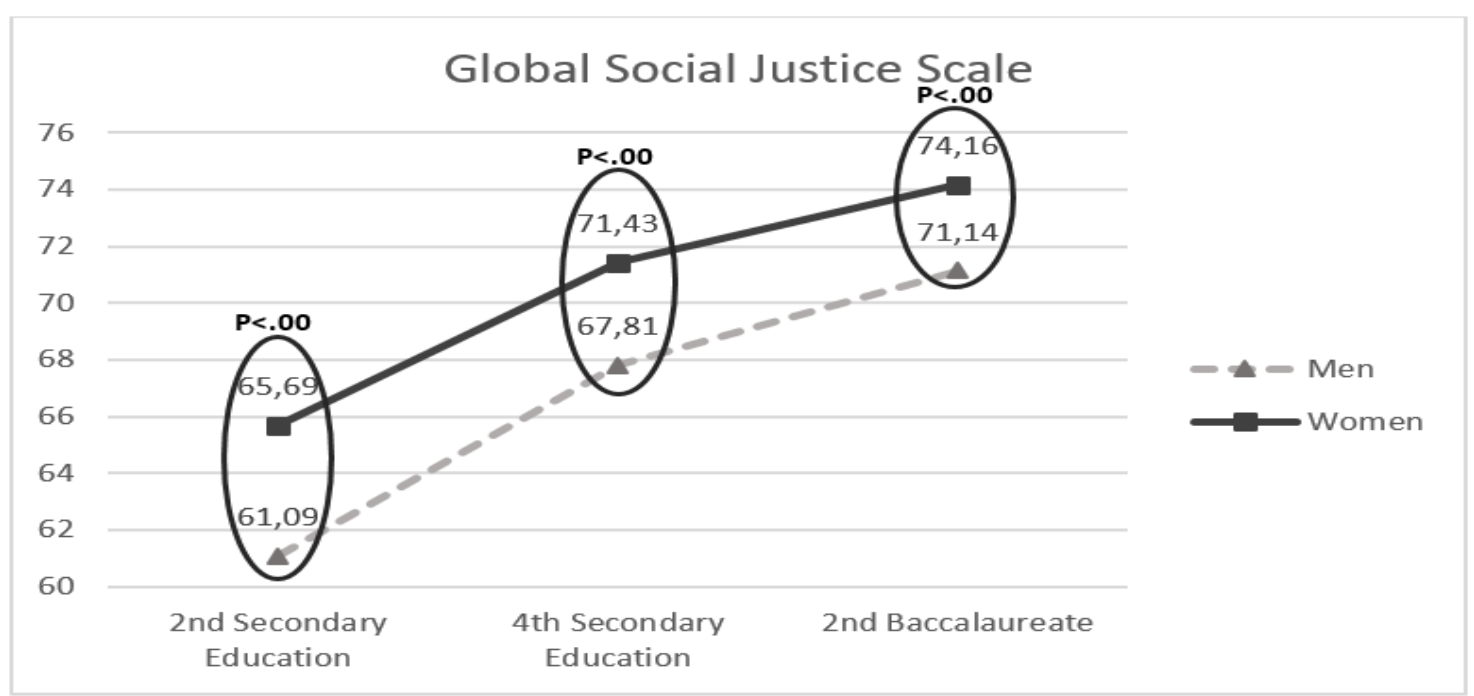

values than males. In addition, in both groups of gender, the mean scores of the groups increase with the educational level and consequently, with the age of the participants.

Fig. 2 Interaction: Educational Level x Gender in the Global Social Justice Scale

\section{Social Justice Subscales: Redistribution, Recognition, Representation}

In the analysis of the three Social Justice Subscales (Redistribution, Recognition, Representation), a mixed design analysis of variance with repeated measures of the variables Gender x Ed. level x Subscale was carried out. The results can be seen in Table 6 . 
Table 6 Tests of intra-subject effects

\begin{tabular}{lrrrrc} 
& $\begin{array}{c}\text { Type III sum } \\
\text { of squares }\end{array}$ & df & F & Sig. & $\begin{array}{c}\text { Partial eta } \\
\text { squared }\end{array}$ \\
\hline Subscale & 99611.966 & 1.978 & 368.738 & $.000^{* * * *}$ & .103 \\
Subscale x Gender & 3658.556 & 1.978 & 13.543 & $.000^{* * *}$ & .004 \\
Subscale x Ed. Level & 2563.176 & 3.956 & 4.744 & $.001 * *$ & .003 \\
Subscale x Gender x Ed. Level & 563.972 & 3.956 & 1.044 & .383 & .001 \\
Error (Subscale) & 869048.974 & 6363.128 & & &
\end{tabular}

**. $p<.01 ;{ }^{* * *} \cdot p<.001$

Regarding the type of subscale, there is a significant main effect $(F(2.6363)=368.74, p<.001 . \eta$

${ }^{2}=.103$ ). Thus, $10.3 \%$ of the variance is explained by this factor.

In order to verify between which Social Justice Subscales appear statistically significant differences, we performed the analysis of pairwise comparisons using the Bonferroni statistic was carried out. Results are shown in Table 7.

Table 7 Paired comparisons of the Social Justice Subscales

\begin{tabular}{clccccc}
\hline $\begin{array}{c}\text { Subscale } \\
\text { (I) }\end{array}$ & Subscale (J) & $\begin{array}{c}\text { Mean } \\
\text { difference (I-J) }\end{array}$ & $\begin{array}{c}\text { Standard } \\
\text { error }\end{array}$ & Sig. & $\begin{array}{c}\text { Lower } \\
\text { limit }\end{array}$ & $\begin{array}{c}\text { Upper } \\
\text { limit }\end{array}$ \\
\hline Redistribution & Recognition & -7.885 & .304 & $.000^{* * *}$ & -8.614 & -7.156 \\
Redistribution & Representation & -4.650 & .293 & $.000^{* * *}$ & -5.352 & -3.947 \\
Recognition & Representation & 3.235 & .278 & $.000^{* * *}$ & 2.570 & 3.901
\end{tabular}

***. $p<.001$

Multiple comparisons in the dimension variable allow us to verify that statistically significant differences appear ( $\mathrm{p}<0.001$ ) among all social justice subscales. The highest mean scores was obtained in the Recognition Subscale ( $M=72.27, S D=14.91)$, followed by the mean score obtained in the Representation Subscale $(M=69.04, S D=13.67)$ while the lowest mean score occurred in the Representation Subcale $(M=64.39, S D=14.52)$.

In addition, Table 6 shows a significant effect of interaction between the variables Subscale $\mathrm{x}$ Gender, $\mathrm{F}$ $(2.6363)=13.54 ; \mathrm{p}<.001 ; \eta^{2}=.004$ although only $0.4 \%$ of the variance can be explained by such interaction. After performing the multiple comparison test with the Bonferroni statistic (Table 8), statistically significant differences $(\mathrm{p}<.001)$ are obtained between males and females in all Social Justice Subscales (redistribution, recognition, representation).

Table 8 Comparisons by gender pairs isolating the Social Justice Subscales

\begin{tabular}{|c|c|c|c|c|c|c|c|}
\hline Subscale & $\begin{array}{l}\text { Gender } \\
\text { (I) }\end{array}$ & $\begin{array}{l}\text { Gender } \\
\text { (J) }\end{array}$ & $\begin{array}{c}\text { Mean difference } \\
(\mathrm{I}-\mathrm{J})\end{array}$ & $\begin{array}{c}\text { Standard } \\
\text { error }\end{array}$ & Sig. & $\begin{array}{c}\text { Lower } \\
\text { limit }\end{array}$ & $\begin{array}{l}\text { Upper } \\
\text { limit }\end{array}$ \\
\hline Redistribution & Female & Male & 1.996 & .497 & $.000 * * *$ & 1.021 & 2.971 \\
\hline Recognition & Female & Male & 4.560 & .501 & $.000 * * *$ & 3.578 & 5.542 \\
\hline Representation & Female & Male & 4.690 & .460 & $.000 * * *$ & 3.787 & 5.592 \\
\hline
\end{tabular}


These results showing the interaction of the three Social Justice Subscales (Redistribution, Representation, Recognition) x Gender can be seen in Figure 3. The same dimensional pattern in the development of Social Justice Subscales was obtained in both gender groups. The lowest mean scores were obtained in the Redistribution Subscale, followed by the mean scores of the Representation Subscale, while the highest mean scores in the Recognition Subscale.

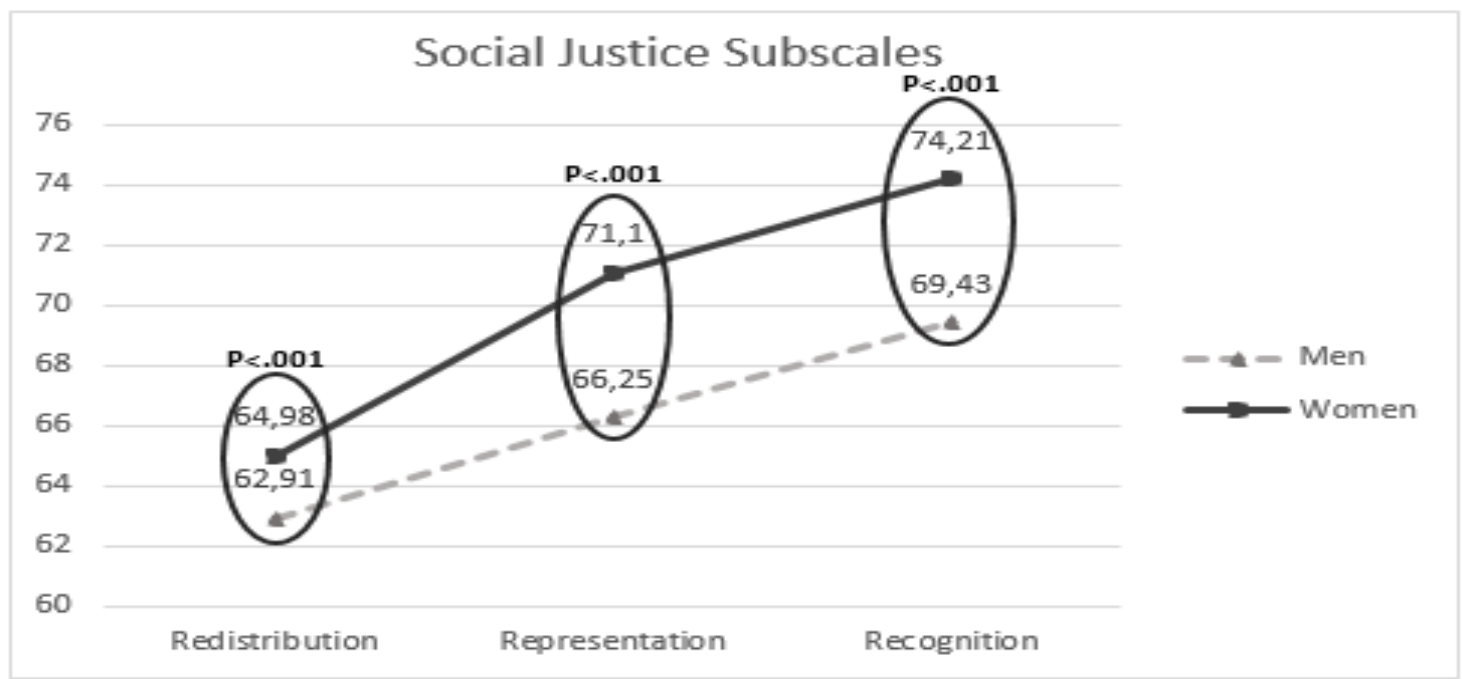

Fig. 3 Interaction: Social Justice Subscales x Gender

There are also statistically significant differences in the effect of the Social Justice Subscales x Ed. Level interaction (Table 6). It can be observed in Table 9 that there are statistically significant differences (p $<.001$ ) among all educational levels in the three Social Justice Subscales (Redistribution, Recognition, Representation).

Table 9 Paired comparisons between the categories isolating the Social Justice Subscales

\begin{tabular}{|c|c|c|c|c|c|c|c|}
\hline $\begin{array}{l}\text { Social Justice } \\
\text { Subscales }\end{array}$ & $\begin{array}{c}\text { Category } \\
\text { (I) }\end{array}$ & $\begin{array}{c}\text { Category } \\
\text { (J) }\end{array}$ & $\begin{array}{c}\text { Mean difference } \\
(\mathrm{I}-\mathrm{J})\end{array}$ & $\begin{array}{c}\text { Standard } \\
\text { Error }\end{array}$ & Sig. & $\begin{array}{l}\text { Lower } \\
\text { limit }\end{array}$ & $\begin{array}{c}\text { Upper } \\
\text { limit }\end{array}$ \\
\hline \multirow[t]{3}{*}{ Redistribution } & $2^{\circ} \mathrm{ESO}$ & $4^{\circ} \mathrm{ESO}$ & $-4,940$ & .583 & $.000 * * *$ & -6.335 & -3.544 \\
\hline & $2^{\circ} \mathrm{ESO}$ & $2^{\circ}$ Bach. & -9.290 & .616 & $.000 * * *$ & -10.766 & -7.814 \\
\hline & $4^{\circ} \mathrm{ESO}$ & $2^{\circ}$ Bach. & -4.350 & .628 & $.000 * * *$ & -5.854 & -2.847 \\
\hline \multirow[t]{3}{*}{ Recognition } & $2^{\circ} \mathrm{ESO}$ & $4^{\circ} \mathrm{ESO}$ & -7.186 & .587 & $.000 * * *$ & -8.591 & -5.781 \\
\hline & $2^{\circ} \mathrm{ESO}$ & $2^{\circ}$ Bach. & -10.067 & .620 & $.000 * * *$ & -11.553 & -8.581 \\
\hline & $4^{\circ} \mathrm{ESO}$ & $2^{\circ}$ Bach. & -2.882 & .632 & $.000 * * *$ & -4.395 & -1.368 \\
\hline \multirow[t]{3}{*}{ Representation } & $2^{\circ} \mathrm{ESO}$ & $4^{\circ} \mathrm{ESO}$ & -6.574 & .539 & $.000 * * *$ & -7.865 & -5.283 \\
\hline & $2^{\circ} \mathrm{ESO}$ & $2^{\circ}$ Bach. & -8.422 & .570 & $.000 * * *$ & -9.787 & -7.056 \\
\hline & $4^{\circ} \mathrm{ESO}$ & $2^{\circ}$ Bach. & -1.847 & .581 & $.004 * *$ & -3.238 & -.457 \\
\hline
\end{tabular}


The results showing the interaction Subscale $x$ Educational Level are presented in Figure 4. It can be observed that in the three educational levels analyzed, the highest mean scores were obtained in the Recognition Subscale and the lowest in the Redistribution Subscale.

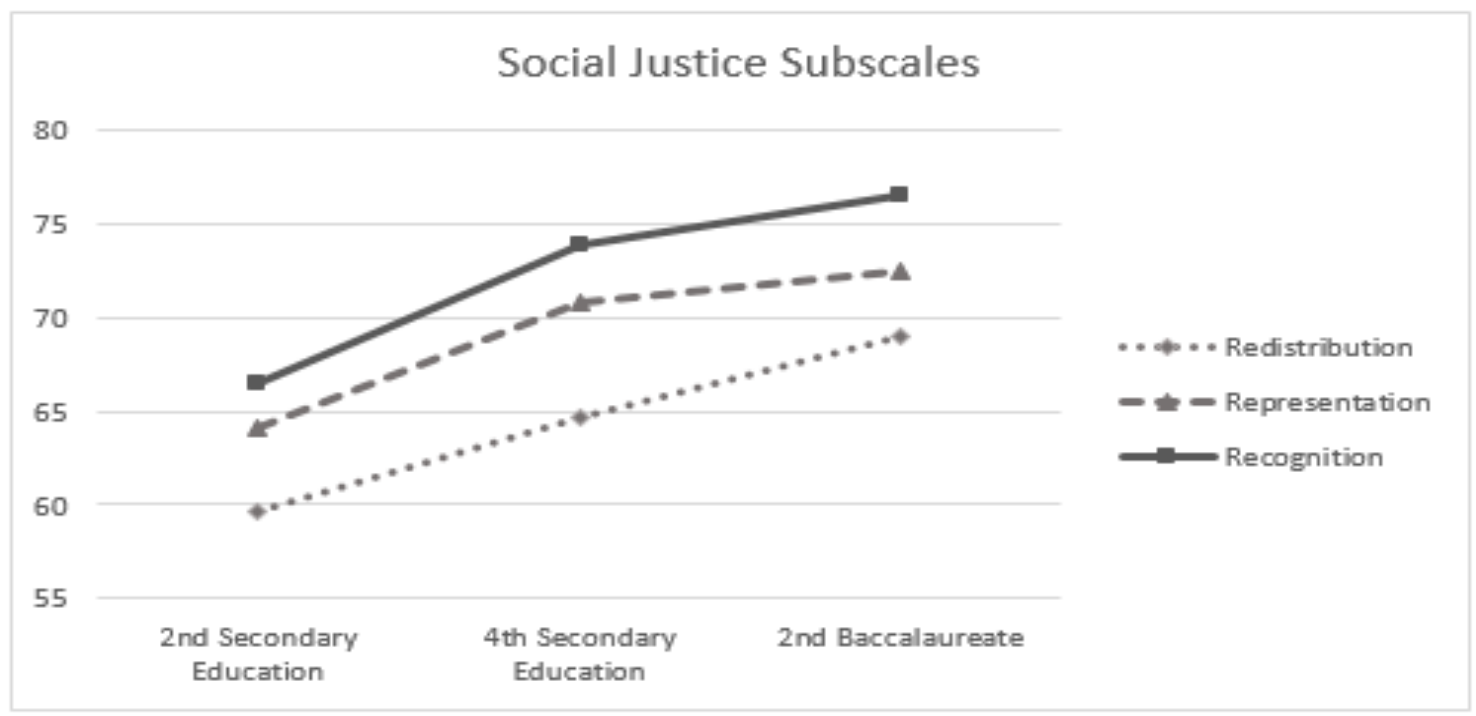

Fig. 4 Estimated measures in the interaction Subscale x Ed. Level

Finally, as can be also observed in Table 6, there is no significant effect in the triple interaction Gender $\mathrm{x}$ Educational Level $x$ Subscale, $F(4.6363)=1.04, \mathrm{p}=.383, \mathrm{\eta}^{2}=.001$. In this case, only $0.1 \%$ of the variance is explained by the interaction between these three factors.

The results of the analysis of the three Social Justice Subscales show results similar to those obtained in the Global Social Justice Scale. The highest mean scores were obtained in the groups of females in the three educational levels analyzed ( $2^{\circ}$ ESO, $4^{\circ}$ ESO, $2^{\circ}$ Bach.) and in the three Social Justice Subscales (Redistribution, Recognition, Representation). In addition, in the three Social Justice Subscales, the mean scores are higher in the higher educational levels, both in the group of females and in the group of males. Regarding the comparison of the three subscales, the lowest mean values were obtained in the Redistribution Subscale, followed by the mean scores of the Representation Subscale and with the highest mean values in the Recognition Subscale. This same tendency is observed in all educational levels and in both groups of genders.

\section{Conclusions and Discussion}

This research examines secondary students' representations of social justice using different type of dilemmas in a large sample of adolescent from different regions of Spain. After the analysis and the results obtained, it can be concluded that the social justice construct is something extremely complex to evaluate, since it requires taking into account a high number of elements and nuances that configure it.

The results show that the three dimensions of social justice model can be very interesting to use in the field of education. Social Justice Representation Questionnaire (SJRQ) allows us to answer the question "What do secondary education students understand about Social Justice?". This instrument allows us to analyze social justice representations of adolescents according to developmental differences, gender and the three dimensions of social justice (redistribution, recognition and representation). SJRQ can also be used as an 
educational tool to improve social justice education and to train social justice oriented citizens (Westheimer, 2015).

We have observed that the social justice representations of Spanish adolescents do not produced in all dimensions equally. It was possible to verify that they follow the same trend in all the educational levels analyzed ( $2^{\circ} \mathrm{ESO}, 4^{\circ} \mathrm{ESO}$ and $2^{\circ} \mathrm{Bach}$.) and in both gender groups. The lowest mean scores were obtained in the Redistribution Subscale, followed by the means obtained in the Representation Subscale and with the highest mean scores in the Recognition Subscale. The results obtained in these three subscales corroborate the findings of other studies (Broido, 2000; Sepúlveda-Parra et al., 2016). These results lead us to interpret that for adolescents it is more complicated to consider social justice in terms of redistribution, possibly because this dimension is more linked on an economic level, and these notions escape from their analysis by handling concepts that they do not usually use in their daily life. In addition, when applying Redistribution criteria, they usually do so based on more egalitarian proposals, as was also the case with the research by Sepúlveda-Parra et al. (2016). This egalitarian approach is done to the detriment of using a fairer treatment of inequalities, which gives greater benefits to the most disadvantaged individuals, according to their specific needs and considering their starting situation (Bolívar, 2016; Lalvani, 2013; Rawls, 1971).

In view also of the results obtained in the three dimension analyzed, it can be seen that for adolescents it is easier to approach social justice based on the recognition of diversity and the appreciation of social and cultural differences. This result is possibly due to the presence of greater linguistic, ethnic and cultural diversity in our current society and in schools. On the other hand, results obtained in the Sepulveda-Parra et al. (2016) research showed that the representations of secondary education students were associated to a greater degree with participation, referring fundamentally to the representativeness of students and their performances in democratic spaces.

The results obtained in Global Social Justice Scale, as well as in the subscales of Redistribution, Recognition and Representation, follow the same tendency obtained in another previous research (JornetMeliá et al., 2015). The mean scores of the participants increase as their age and educational level increase, confirming that the social justice representations of secondary education students follow a developmental trend.

Regarding gender, females have obtained significantly higher mean scores than males in both the Global Social Justice Scale general social justice Scale and the Social Justice Subscales of Redistribution, Recognition and Representation. Previous studies (Hurtado et al., 2002; Murillo et al., 2014) obtained similar results showing females a more tendency towards social justice than men.

\section{Implications, limitations and future lines of research}

This research has been designed from an empirical approach, using quantitative methodology. To deepen the analysis and results obtained, it would be convenient to support the results with qualitative strategies, such as interviews or discussion groups. These complementary strategies, would allow obtaining greater precision in the responses of the participants in order to arrive at a more comprehensive substantiation of the proposed research objective. In line with this, focus groups have been conducted with secondary 
education students on 15 of the dilemmas of the questionnaire. The results of this work are currently being analyzed.

It would be important to be able to advance with future research work in the analysis of these representations in other populations and contexts, as well as in their relationship with other types of variables. Following the trend of other previous research, in future studies it would be interesting to relate the evaluation of social justice representations with other variables such as the personality of the participants (Beer et al., 2012), their previous learning lessons on social justice issues (Broido, 2000; Cochran-Smith, 2010) and their experiences of injustice lived or witnessed (Beer et al., 2012; Caldwell \& Vera, 2010; Hurtado, 2006; Jornet-Meliá et al., 2015).

On the other hand, it would be convenient to carry out longitudinal studies with the same participants at different times, to observe the evolution of social justice representations, and to see if the results obtained improve, worsen or are maintained. We need to understand the nuances of the representations of social justice that the students present much more, and how they are change and progress through time.

Future research should continue to focus on how students conceptualize what it means to work for social justice, examining how individuals move from awareness and representations of social justice to actively participating and getting involved in deeper social change.

It is convenient to evaluate the representations that students have about social justice to be able to elaborate programs adapted to their different levels of understanding. As indicated by Torres-Harding, et al. (2014), examining how students conceptualize social justice and related constructs is important for educators to foster dialogue and critical discussions around the issue of social justice in their classes. Only when we are aware of the inequalities of society can we intervene on injustice, and this promotion of social justice can only be achieved by improving redistribution, recognition and representation.

\section{References}

Adams, M. \& Bell, L. A. (Eds.). (2016). Teaching for diversity and social justice. New York, NY: Routledge.

Apple, M. W. (Ed.). (2009). Global crises, social justice, and education. New York, NY: Routledge.

Ayers, W., Quinn, T. M. \& Stovall, D. (Eds.). (2009). Handbook of social justice in education. New York, NY: Routledge.

Beer, A. M., Spanierman, L. B., Greene, J. C. \& Todd, N. R. (2012). Counseling psychology trainees' perceptions of training and commitments to social justice. Journal of Counseling Psychology, 59(1), 120.

Blum, G., Wilson, M. \& Patish, Y. (2015). Moving toward a more socially just classroom through teacher preparation for inclusion. Catalyst: A Social Justice Forum, 5(1), 4-13.

Bolívar, A. (2016). Equidad educativa y teorías de la justicia [Educational equity and theories of justice]. REICE. Revista Iberoamericana sobre Calidad, Eficacia y Cambio en Educación, 3(2).

Bonnycastle, C. (2011). Social Justice along a Continuum: A Relational Illustrative Model. Social Service Review, 85(2), 267-295. 
Brighouse, H. (2000). School choice and social justice. New York, NY: Oxford University Press.

Broido, E. M. (2000). The development of social justice allies during college: A phenomenological investigation. Journal of College Student Development, 41(1), 3-18.

Caldwell, J. C. \& Vera, E. M. (2010). Critical incidents in counseling psychology professionals' and trainees' social justice orientation development. Training and Education in Professional Psychology, 4(3), 163-176.

Cazden, C. (2012). A framework for social justice in education. International Journal of Educational Psychology, 1(3), 178-198.

Chen-Hayes, S. F. (2001). Social justice advocacy readiness questionnaire. Journal of Gay \& Lesbian Social Services, 13(1), 191-203.

Cochran-Smith, M. (2008). The new teacher education in the United States: Directions forward. Teachers and Teaching: theory and practice, 14(4), 271-282.

Cochran-Smith, M. (2010). Toward a theory of teacher education for social justice. In M. Fullan, A. Hargreaves, D. Hopkins, y A. Lieberman (Eds.), The Second international handbook of educational change (pp. 445-467). New York, NY: Springer Publishing.

Cole, M. (2017). Education, equality and human rights: Issues of gender, race, sexuality, disability and social class. New York, NY: Routledge.

Colquitt, J. (2001). On the dimensionality of organizational justice: A construct validation of a measure. Journal of Applied Psychology, 86(3), 386-400.

Corning, A. F. \& Myers, D. J. (2002). Individual orientation toward engagement in social action. Political Psychology, 23(4), 703-729.

Dworkin, R. (1981). What is equality? Part 2: Equality of resources. Philosophy \& Public Affairs, 10(4), 283-345.

Fraser, N. (2008). Scales of Justice: Reimagining Political Space in a Globalizing World. New York, NY: Columbia University Press.

Fraser, N. \& Honneth, A. (2003). Redistribution or recognition? A political-philosophical exchange. London, UK: Verso Press.

Gewirtz, S. (2006). Towards a Contextualized Analysis of Social Justice in Education. Educational Philosophy and Theory, 38(1), 69-81.

Goodman, D. J. (2000). Motivating people from privileged groups to support social justice. Teachers College Record, 102(6), 1061-1085.

Honneth, A. (2007). Reificación. Un estudio en la teoría del reconocimiento [Reification: a study in recognition theory]. Buenos Aires: Katz.

Hurtado, S. (2006). Linking diversity with the educational and civic missions of higher education. The Review of Higher Education, 30(2), 185-196.

Hurtado, S., Engberg, M. E., Ponjuan, L. \& Landreman, L. (2002). Students' precollege preparation for participation in a diverse democracy. Research in Higher Education, 43(2), 163-186.

Irvine, J. J. (2003). Educating teachers for diversity: Seeing with a cultural eye. New York, NY: Teachers College Press.

Jornet-Meliá, J. M., Sancho-Álvarez, C. \& Bakieva, M. (2015). Diseño y validación del constructo teórico de justicia social percibida por el alumnado en los centros escolares [Design and validation of the 
theoretical construct of social justice perceived by students in schools]. Revista Internacional de Educación para la Justicia Social, 4(2), 111-126.

Lalvani, P. (2013). Privilege, compromise, or social justice: Teachers' conceptualizations of inclusive education. Disability \& Society, 28(1), 14-27.

Lynch, K. \& Lodge, A. (2002). Equality and power in schools: Redistribution, recognition and representation. London, UK: Routledge Falmer.

Ludlow, L. H., Enterline, S. E. \& Cochran-Smith, M. (2008). Learning to teach for social justice-beliefs scale: An application of Rasch measurement principles. Measurement and Evaluation in Counseling and Development, 40(4), 194-214.

Marszalek, J. M., Barber, C., \& Nilsson, J. E. (2017). Development of the Social Issues Advocacy Scale-2 (SIAS-2). Social Justice Research, 30(2), 117-144.

McDonald, M. (2005).The integration of social justice in teacher education: Dimensions of prospective teachers' opportunities to learn. Journal of Teacher Education, 56(5), 418-435.

McDonald, M. (2008). The pedagogy of assignments in social justice teacher education. Equity \& Excellence in Education, 41(2), 151-167.

Miller, D. (1999). Principles of social justice. Cambridge, MA: Harvard University Press.

Miller, M.J., Sendrowitz, K., Connacher, C., Blanco, S., Muñiz de la Peña, C., Bernadi, S. \& Morere, L. (2009). College students' social justice interest and commitment: A social-cognitive perspective. Journal of Counseling Psychology, 56(4), 495-507.

Miller, M. J. \& Sendrowitz, K. (2011). Counseling psychology trainees' social justice interest and commitment. Journal of Counseling Psychology, 58(2), 159.

Murillo, F. J. \& Hernández Castilla, R. (2011). Trabajar por la justicia social desde la educación [Working for social justice from education]. Revista Electrónica Iberoamericana sobre Calidad, Eficacia y Cambio en Educación (REICE), 9(4), 3-6.

Murillo, F. J., Hernández-Castilla, R., Hidalgo, N. \& Martínez-Garrido, C. (2014). Elaboración y evaluación psicométrica de la Escala de Actitudes hacia la Justica Social en Educación (EAJSE) [Development and psychometric evaluation of the Scale of Attitudes toward Social Justice in Education]. Revista Internacional de Educación para la Justicia Social (RIEJS), 3(2), 215-233.

Nilsson, J. E. \& Schmidt, C. K. (2005). Social justice advocacy among graduate students in counseling: An initial exploration. Journal of College Student Development, 46, 267-279.

Nilsson, J. E., Marszalek, J. M., Linnemeyer, R. M., Bahner, A. D. \& Misialek, L. H. (2011). Development and assessment of the social issues advocacy scale. Educational and Psychological Measurement, 71(1), 258-275.

North, C. E. (2006). More than words? Delving into the substantive meaning(s) of "social justice" in education. Review of Educational Research, 76(4), 507-535.

Novak, M. (2000). Defining social justice. First Things, 108, 11-13.

Nussbaum, M. (2006). Frontiers of justice: disability, nationality, species membership. Cambridge, MA: Belknap Press.

Nussbaum, M. (2011). Creating capabilities. Cambridge, MA: Harvard University Press.

Patterson, N., Doppen, F. \& Misco, T. (2012). Beyond personally responsible: A study of teacher conceptualizations of citizenship education. Education, Citizenship and Social Justice, 7(2), 191206. 
Rasinski, K. A. (1987). What's fair is fair-or is it? value differences underlying public views about social justice. Journal of Personality and Social Psychology, 53(1), 201-211.

Rawls, J. (1971). A theory of justice. New York, NY: Oxford University Press.

Reagan, E. M., Chen, C., \& Vernikoff, L. (2016). "Teachers are work in progress": A mixed methods study of teaching residents' beliefs and articulations of teaching for social justice. Teaching and Teacher Education, 59, 213-227.

Ritchhart, M. (2002). Development of the Social Activism Beliefs Rating scale (SABR): an instrument to measure psychologists' attitudes toward social activism (Tesis doctoral). Oklahoma State University, OK.

Sainz, V., García, T., Pérez-Manjarrez, E., Juanes, A., Fernández-González, T., Seguro, V. \& Agustín, S. (2013). Validation of a social justice questionnaire. En P. Cunningham (Ed.), Identities and Citizenship Education: Controversy, crisis and challenges (pp. 516-521). London, UK: CiCe.

Sen, A. (2009). The idea of justice. London, UK: Penguin.

Sepúlveda-Parra, C., Brunaud-Vega, V. \& Carreño González, C. (2016). Justicia social en la escuela: Representaciones de estudiantes de educación secundaria y desafíos para la formación del profesorado [Social justice in school: representations of students of secondary education and challenges for teacher training]. Revista Internacional de Educación para la Justicia Social (RIEJS), 5(2), 109-129.

Slee, R. (2001). Social justice and the changing directions in educational research: The case of inclusive education. International journal of inclusive education, 5(2), 167-177.

Stiglitz, J. E. (2012). The price of inequality: How today's divided society endangers our future. New York, NY: W.W. Norton \& Company.

Rasinski, K. A. (1987). What's fair is fair-or is it? value differences underlying public views about social justice. Journal of Personality and Social Psychology, 53(1), 201-211.

Taylor, C. (1993). El multiculturalismo y la política del reconocimiento. México: Fondo de Cultura Económica.

Tikly, L. (2010). Towards a framework for understanding the quality of education. Bristol, UK: EdQual.

Tikly, L. \& Barrett, A. M. (2011). Social justice, capabilities and the quality of education in low income countries. International Journal of Educational Development, 31(1), 3-14.

Torres-Harding, S. R., Siers, B. \& Olson, B. D. (2012). Development and psychometric evaluation of the Social Justice Scale (SJS). American journal of community psychology, 50(1), 77-88.

Torres-Harding, S. R., Steele, C., Schulz, E., Taha, F. \& Pico, C. (2014). Student perceptions of social justice and social justice activities. Education, Citizenship and Social Justice, 9(1), 55-66.

Walker, M. (2006). Towards a capability-based theory of social justice for education policy-making. Journal of Education Policy, 21(2), 163-185.

Westheimer, J. (2015). What Kind of Citizen? Educating Our Children for the Common Good. New York, NY: Teachers College Press.

Young, I. M. (1990). Justice and the politics of difference. Princeton, NJ: Princeton University Press.

Young, I. M. \& Nussbaum, M. (2013). Responsibility for justice. New York, NY: Oxford University Press.

Zeichner, K. M. (2009). Teacher education and the struggle for social justice. New York, NY: Routledge. 